\title{
2021 Handbook of Florida Water Regulation: Pollutant Storage Tank Systems ${ }^{1}$
}

\author{
Michael T. Olexa, Tatiana Borisova, and Jana Caracciolo
}

\section{Preface}

This handbook is designed to provide an accurate, current, and authoritative summary of the principal federal and state (Florida) laws that directly or indirectly relate to agriculture. This handbook provides a basic overview of the many rights and responsibilities that farmers and farmland owners have under both federal and state laws as well as the appropriate contact information to obtain more detailed information. However, the reader should be aware that because the laws, administrative rulings, and court decisions on which this handbook is based are subject to constant revision, portions of this publication could become outdated at any time. Several details of cited laws are also left out due to space limitations. This handbook is provided as an educational text for those interested in water use and water resource issues in Florida.

This handbook is distributed with the understanding that the authors are not engaged in rendering legal or other professional advice, and the information contained herein should not be regarded as a substitute for professional advice. This handbook is not all inclusive in providing information to achieve compliance with the federal and state laws and regulations governing water protection. For these reasons, the use of these materials by any person constitutes an agreement to hold harmless the authors, the UF/IFAS Center for Agricultural and Natural Resource Law, and UF/IFAS Extension for any liability claims, damages, or expenses that may be incurred by any person as a result of reference to or reliance on the information contained in this handbook. Note: UF/IFAS is the acronym for University of Florida, Institute of Food and Agricultural Sciences.

\section{PSTS Overview}

A pollutant storage tank system (PSTS) is a tank used to contain regulated substances, its integral piping, and all its components, including dispensers, spill containment systems, overfill protection systems, secondary containment systems, and any associated release detection equipment.

\section{What is a pollutant?}

A tank will fall within the scope of the regulations if it holds a pollutant. A "pollutant" is defined by Florida Statute 376.031 as any of the following:

- Oil in any form

- Gasoline

- Pesticide

- Ammonia

- Chlorine compound

- Derivatives of the above,

- Excluding liquid petroleum gas

1. This document is FE613, one of a series of the Food and Resource Economics Department, UF/IFAS Extension. Original publication date October 1998. Revised June 2017 and April 2021. Visit the EDIS website at https://edis.ifas.ufl.edu for the currently supported version of this publication.

2. Michael T. Olexa, professor, Food and Resource Economics Department, and director, UF/IFAS Center for Agricultural and Natural Resource Law; Tatiana Borisova, associate professor, Food and Resource Economics Department; and Jana Caracciolo, student, Levin College of Law; UF/IFAS Extension, Gainesville, FL 32611.

The Institute of Food and Agricultural Sciences (IFAS) is an Equal Opportunity Institution authorized to provide research, educational information and other services

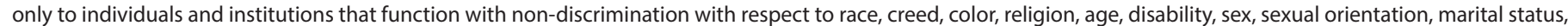

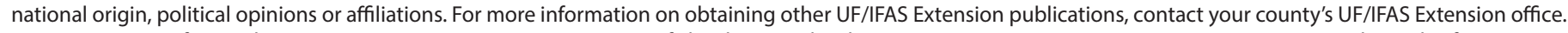
U.S. Department of Agriculture, UF/IFAS Extension Service, University of Florida, IFAS, Florida A \& M University Cooperative Extension Program, and Boards of County Commissioners Cooperating. Nick T. Place, dean for UF/IFAS Extension. 


\section{Who regulates pollutant storage tank systems?}

Statewide regulation of stationary storage tank systems is primarily the domain of the Florida Department of Environmental Protection (FDEP). FDEP has the power to regulate pollutant storage tanks through the Florida Statutes (particularly Chapter 376, Pollutant Discharge Prevention and Removal). Consequently, FDEP is the state agency who primarily regulates pollutant storage tanks. However, the regulations allow individual county governments to promulgate their own regulations. These local regulations can be more stringent than those of FDEP. County authorities should be consulted even if the storage tank activity or condition is apparently within the statewide standards.

\section{Which systems are regulated?}

The bulk of the regulations only apply to storage tank systems whose individual storage capacity is greater than 110 gallons. Smaller tanks only need to comply with the general requirements that they do not discharge their contents into the environment and that they conform to fire prevention standards.

There is a list of 22 types of underground storage tank systems that are exempt in Florida (based on 62-761.300(2), Florida Administrative Code). For example, any agricultural storage tank system with a capacity of 550 gallons or less is exempt from regulation (note that any discharges or leaks will still be regulated under the federal Resource Conservation and Recovery Act, the state's Resource Recovery and Management Act, and any other statute that may apply). If you do not fall within these exemptions, we recommend that you contact the regional FDEP office in your area for more information on the regulation of underground storage tanks (FE786, Contact Agencies). You can also access additional materials related to the storage Tank Compliance on FDEP website at https://floridadep. gov/waste/storage-tank-compliance.

In turn, an "aboveground" tank has no more than 10 percent of its volume buried (including integral piping.) Aboveground systems are subject to less restrictive regulation than buried systems: they are subject to requirements described in Chapter 376, Florida Statutes only if they have a storage capacity greater than 550 gallons. These tanks, however, are subject to similar recordkeeping rules as buried tanks and must be equipped with an impervious containment barrier to catch spills. Furthermore, any part of the tank in contact with the ground must be protected against corrosion.

\section{What are the rules for system owners?}

Other than federal, state, and local permits required for the physical construction and installation of storage tank systems, there are no permitting requirements stemming directly from FDEP. However, system owners must do the following:

- Register tanks with FDEP 30 days before the start of the installation

- Notify FDEP 30 days before the closure of any storage tank system or 10 days before replacing or upgrading a system

- Notify FDEP within 30 days of a change in ownership of a storage tank system

- Report immediately any spills that represent any threat to environmental quality (this includes discharges in excess of 100 gallons into pervious surfaces)

\section{What are the construction, repair, and testing standards?}

All new tanks must comply with the FDEP list of safety requirements, including double-wall or reinforced construction, monitoring systems/wells, strike plates, electric isolation systems, and other such specifics. Similar requirements have been promulgated for the pipe systems connecting to the tanks, and corrosion protection is required.

FDEP also provides extensive requirements for testing the integrity of tanks, and for taking samples from tanks, monitored wells, and soil in the vicinity of the tank. All testing must be performed by trained personnel. Although the testing intervals are specified in the rules, FDEP retains the authority to order complete system testing whenever it deems it necessary based on the following:

- The operator's failure to comply with rules

- Evidence of a discharge or of contamination in the area

Operators of storage facilities are required to keep records for FDEP inspection. These records must include the results of all tests and inspections as well as maintenance and inventory notes on the tanks or their contents. The records must date back at least two years and must be made available to FDEP within five working days' notice.

\section{What are the cleanup safeguards and procedures?}

Operators may be required by both state and federal law to adopt a Spill Prevention Control and Countermeasure Plan before installing a tank. This is pursuant to the federal 
policy of monitoring anyone with the potential to pollute the environment through petroleum discharge. This plan, or an FDEP-approved alternative plan, should detail the drainage and other engineering measures taken to mitigate the damage of spills and may require an advance, written commitment of materials and manpower that will be used to clean up any spills that occur.

As noted earlier, spills must be reported immediately, and the owner/operator must take immediate steps to "contain, remove, or abate the discharge." If groundwater quality is threatened by the spill, FDEP may also order the owner to take whatever corrective action is necessary to reduce the hazard to the public.

\section{What is the proper procedure for tank closure?}

The proper procedure for underground and aboveground storage tank closure is as follows:

- Notify FDEP at 30 to 45 days before you close your storage tank system

- Fill out a Closure Integrity Evaluation form no more than 45 days prior to closure and submit to the appropriate county (Closure Integrity Evaluation form can be found on FDEP's website, for underground storage tanks:

https://floridadep.gov/waste/permitting-complianceassistance/forms/closure-integrity-evaluation-reportform-usts; and for aboveground storage tanks: https:// floridadep.gov/waste/permitting-compliance-assistance/ forms/closure-integrity-evaluation-report-form-asts)

- Remove all liquids and accumulated sludge

- Disconnect and cap all integral piping

- Have certified contractor remove and dispose of tank or fill tank with sand, concrete, or similar inert material

For more information on closure requirements and closure forms, see https://floridadep.gov/ waste/permitting-compliance-assistance/content/ storage-tank-system-rules-forms-and-reference

Under the Comprehensive Environmental Response, Compensation, and Liability Act (CERCLA), landowners may be held liable for leakage from tanks that have been abandoned on their property by previous owners. Consequently, buyers should thoroughly inspect the property before purchase (see FE584, CERCLA). If leaking tanks are discovered, the cleanup may be supervised by the landowner or by the United States Department of Environmental Protection Agency (EPA). It will inevitably be costly.

\section{Sources}

Chapter 376, Florida Statutes, Sections 376.303

Title 62-761, Florida Administrative Code

Title 62-762, Florida Administrative Code

40 Code for Federal Regulations, Sections 280 and 281

\section{Acknowledgments}

The authors are indebted to the personnel of both state and federal agencies who provided their time and advice in the preparation of this handbook. We acknowledge Carol Fountain and Susan Gildersleeve at the University of Florida for their assistance in editing this handbook. We also acknowledge funding received for updating this publication from the James S. and Dorothy F. Wershow Agricultural Law Endowment. 